\title{
An uncommon cause for compressive myelopathy
}

\author{
Sahana Shetty, Raghavendra Nayak, Nitin Kapoor, Thomas Vizhalil Paul
}

Department of Endocrinology, Christian Medical College, Vellore, Tamil Nadu, India

\section{Correspondenc to}

Professor Thomas Vizhalil Paul, thomasvpaul@yahoo.com

Accepted 30 January 2015

\section{DESCRIPTION}

A 35-year old man presented with a history of low backache associated with progressive weakness of lower limbs of 3 years' duration. There was shooting pain radiating down to both lower limbs. There was also a similar history of back pain and stiffness among his other siblings and a few neighbours.

On examination, there was mottling of the teeth with discolouration. The patient had spastic paraparesis and marked limitation of movements at the thoraco lumbar spine. X-ray of the spine showed sclerotic vertebrae with anterior longitudinal ligamental calcification (figure 1) and there was intraosseous membrane ossification at the forearm (figure 2).

Biochemical investigations were as follows: serum corrected calcium: $9.3 \mathrm{mg} / \mathrm{dL}$ (N: 8.2-10.3), serum phosphorus: $3.8 \mathrm{mg} / \mathrm{dL}(\mathrm{N}: 2.5-4)$, serum alkaline phosphatase: $120 \mathrm{U} / \mathrm{L}(\mathrm{N}: 40-125)$, serum creatinine: $1.1 \mathrm{mg} / \mathrm{dL}(\mathrm{N}$ : $0.6-1.2)$, intact parathyroid hormone: $33.2 \mathrm{pg} / \mathrm{mL}$ (N: 8.0-50), $25(\mathrm{OH})$ vitamin D: $37 \mathrm{ng} / \mathrm{mL}(\mathrm{N}: 30-70 \mathrm{ng} / \mathrm{mL})$, venous bicarbonate: $25 \mathrm{mmol} / \mathrm{L}$ (N: 21-28), $24 \mathrm{~h}$ urinefluoride: $3.5 \mathrm{ppm}$

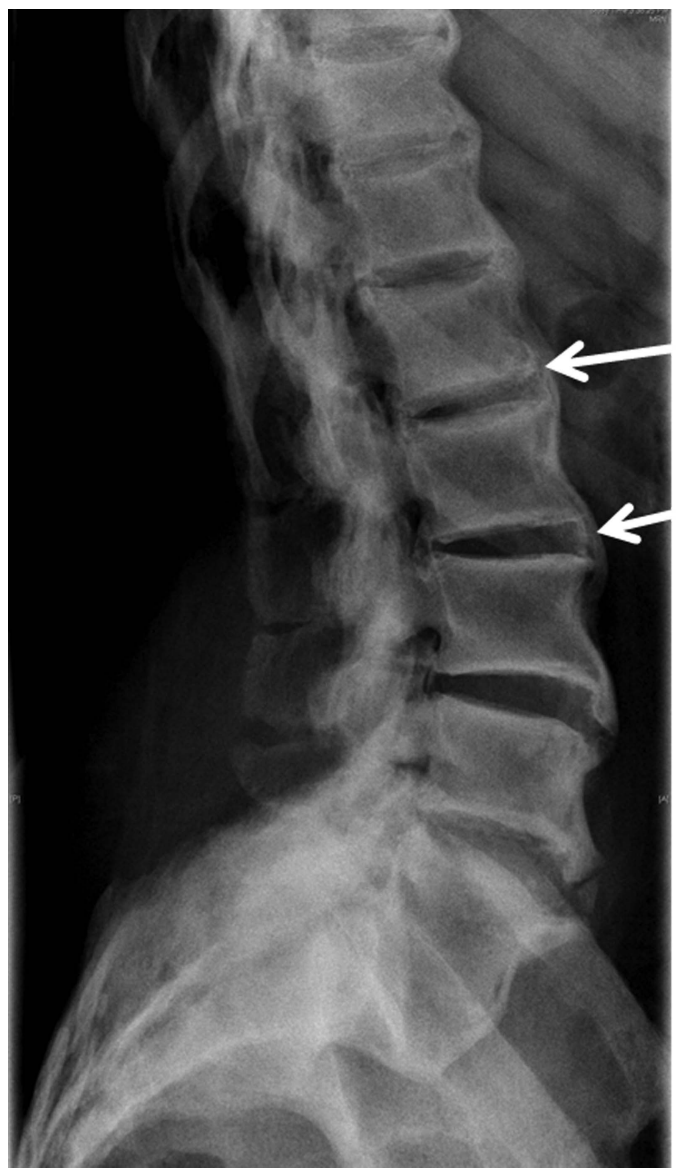

Figure $1 \quad X$-Ray of the spine showing diffuse osteosclerosis and irregular osteophytes.

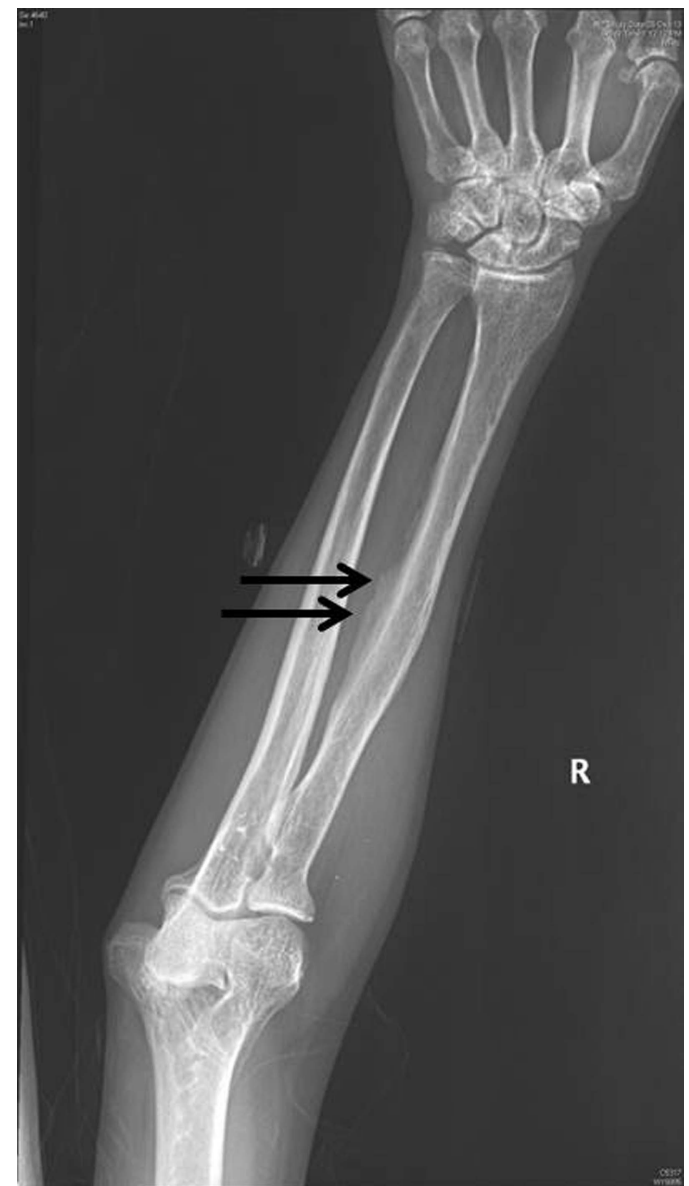

Figure 2 X-Ray of the forearm (right) showing interosseous membrane classification.

$(\mathrm{N}:<1.0 \mathrm{ppm})$. The mottling of the teeth, X-ray findings of the spine and intraosseous membrane ossification at forearm along with elevated urine fluoride level were diagnostic of fluorosis.

Fluorosis, a metabolic bone disease (due to longterm exposure to large amount of fluoride) is an important health problem in Asian countries, including India, China, Japan and Afghanistan, as at least one-fourth of the earth's fluoride crust is found in these regions. ${ }^{1}$ Age, sex, calcium intake, dose and duration of fluoride intake are factors which influence the manifestation of fluorosis. ${ }^{2}$ Long-term exposure to fluoride may result in mottling of teeth, diffused bone pain, stiffness myelopathy, radiculopathy and paralysis of the cranial secondary to compression exerted by exostosis and calcifications on nerve structures.

Osteosclerosis, osteophytosis and ligamentous calcifications are the characteristic triad of fluorosis. Osteosclerosis is also observed in bone metastases, renal osteodystrophy, Paget's disease and other sclerotic disorders such as osteopetrosis. The osteophytosis may be seen in spondylosis deformans. 
The ossification of the ligaments and tendons is usually a feature also evident in diffuse idiopathic skeletal hyperostosis. ${ }^{3}$

\section{Learning points}

- Fluorosis is a chronic metabolic bone and joint disease caused by ingestion of large amounts of fluoride either through water from deep bore wells or as part of occupational exposure to fluoride dust or fumes.

- Radiographs of the spine and forearm usually display features typical of fluorosis, which include osteosclerosis, osteophytosis and ligamentous calcifications; diagnostic confirmation is obtained by determining the urinary fluoride.

- Since there is no treatment for fluorosis and the disease is irreversible, primary measures such as provision of surface water and defluoridation of the water and an early diagnosis with further avoidance of exposure to fluoride, remain the main strategies in endemic areas.
Contributors SS and RN wrote the manuscript. NK and TVP reviewed the manuscript. SS, RN, NK and TVP approved the final manuscript.

Competing interests None.

Patient consent Obtained.

Provenance and peer review Not commissioned; externally peer reviewed.

\section{REFERENCES}

1 Krishnamachari KA. Skeletal fluorosis in humans: a review of recent progress in the understanding of the disease. Prog Food Nutr Sci.1986;10:279-314.

2 Reddy DR. Neurology of endemic skeletal fluorosis. Neurol India 2009;57:7-12.

3 Dhar V, Bhatnagar M. Physiology and toxicity of fluoride. Indian I Dent Res 2009:20:350-5.

Copyright 2015 BMJ Publishing Group. All rights reserved. For permission to reuse any of this content visit http://group.bmj.com/group/rights-licensing/permissions.

BMJ Case Report Fellows may re-use this article for personal use and teaching without any further permission.

Become a Fellow of BMJ Case Reports today and you can:

- Submit as many cases as you like

- Enjoy fast sympathetic peer review and rapid publication of accepted articles

- Access all the published articles

- Re-use any of the published material for personal use and teaching without further permission

For information on Institutional Fellowships contact consortiasales@bmjgroup.com

Visit casereports.bmj.com for more articles like this and to become a Fellow 